\title{
Failure of Foreign Aid in Developing Countries: A Quest for Alternatives
}

Niyonkuru $F^{*}$

Office Administrator at SPANCO Charitable Organization Human Resources, Ghana

\begin{abstract}
Adequate development strategies and policies to be applied in the developing countries to eradicate poverty have been on trial with no effect ever since the era of structural adjustment programs. The state of underdevelopment of most African countries and many developing countries can be accounted to a variety of factors, many of which are those supposed to bring about remedy. The paper examines, the nature, the relevance of foreign aid given to developing countries and assesses level of influence of other alternatives to development available for the continent. Foreign Aid has been contracted for development projects' support, supplementing national budget, debt relief, aid to attain the set Millennium Development Goals... which were supposed to lead those countries to middle income status etc. Loans and grants given to accelerate poverty reduction programs have shown little aptitude to reduce poverty. The study showed that the given aid is shrouded with hidden agenda from donors who set unbearable conditionality, hard to meet to yield desired results. At one hand, the inefficacy of foreign aid to eradicate poverty was seen as inherent to its nature and at the other hand, as results of its management and cycling by recipients. Far to bear fruits, the conditionalities attached to some of contacted economic bail out ( from the IMF and WB) to address economic crisis countries can face, it was rather seen as harmful to vulnerable citizens due to its stringent austerity measures and though it may bring about economic stabilization, no indices of economic growth and people's welfare could be measured. Despite diversified kinds of intervention of the non-governmental organizations and civil societies in their variety social services delivery (in health, mass education and mobilization, education, human rights preservation...), their capacity to lead our nations to macroeconomic growth were not evident as in their good work, face numerous barriers from both donors and governments recipients. Their problem solving strategies fail to be counted on for a sustained macroeconomic development. The New Partnership for African Development (NEPAD) which came as a well thought and designed new re-engagement to lay solid foundation for the renewal of African condition, despite its efforts to eradicate poverty, to put African countries on the path of sustainable growth, to halt the marginalization of the African continent in the globalization process, to integrate the continent in the global economy and accelerate the women's role in development agenda. These beautiful verbiage formulations are yet to be seen on the ground and it seems it had failed to get to its desired destination. The paper recommends a new reawakening in the realm of cooperation and integration among African nations. If foreign aid it to yield good results, the paper suggest casts off the recourse to unfruitful conditionalities which was seen rather harmful. Other development entities such as nonprofit making organizations should help countries invest in long term projects in full workable public-private partnerships model while the state's role should avoid be investing in both infrastructure and human capital, embark on monetary and fiscal discipline and create enabling environment for business and institutional administrations for aid to produce good results.
\end{abstract}

Keywords: Foreign aid; Developing countries; Conditionality; Poverty; Economic growth

\section{Introduction}

The state has been long considered as the sole vector and agent of development before other international financial institutions (IMF, WB, NGOs...) came to supplement the state's role. Globalization and neoliberalization dynamics changed the view of the development idealists. The state is however the main actor in the development process. Its relationship with economy should be translated into capital formation, provision of infrastructural and legal framework development projects have to undertake. The non-governmental organizations and the third sector which are virtually the second engine of the economy have a tremendous role to play as their autonomy grows as the state's declines. In times of incapacity of the state to meet the economic commitment to render its primary services to the society, donors (both local and international) lenders of all origins intervene through loans, grants, aid etc. The Official Development Assistance (ODA) played this regulatory role for long before Breton woods institutions took over to assist countries facing hardship to deliver to the people by giving loans, economic bail out interventions and aid, with an aim of helping nations achieve middle come status. This paper questions the significance, the purpose, justification of aid given to development nation. It will evaluate the significance and impact Foreign Aid has in the life of the economy of our developing countries. It will be noteworthy to equally assess the level of performance of other development alternatives taken by developing countries, their strength and failure to eradicate poverty.

\section{Foreign aid to developing countries}

Aid given to developing countries is meant to help these countries develop and accomplish their development projects. These aids may come from former colonial monopole to strengthen bilateral ties between the former colonies and their colonial powers. Loans can be given to be spent on goods bought from donor countries where consultancy fee are always inclusive. In Africa, foreign aid comes in diverse forms: Support of projects of investment, budget support, technical assistance of various projects, debt relief etc. It may be given in forms of grants which may not have to be paid, loans payable at lower interest rate over a longer period, contributions or aid from UN

*Corresponding author: Niyonkuru F, Office Administrator at SPANCO Charitable Organization Human Resources, Ghana, Tel: 2486261834; E-mail: fulniyo2011@gmail.com

Received June 03, 2016; Accepted June 15, 2016; Published June 25, 2016

Citation: Niyonkuru F (2016) Failure of Foreign Aid in Developing Countries: A Quest for Alternatives. Bus Eco J 7: 231. doi:10.4172/2151-6219.1000231

Copyright: (c) 2016 Niyonkuru F. This is an open-access article distributed unde the terms of the Creative Commons Attribution License, which permits unrestricted use, distribution, and reproduction in any medium, provided the original author and source are credited. 
institutions, IMF, WB or regional banks. For instance, the USA gives its aid to countries to support: State capacity building to strengthen security and in conflict management and resolution. Or else, build up business partnership by supporting the generation of demand of US goods.

Nature of foreign aid: The aid is classified in key thematic areas: Investment in people (social welfare provision), environmental protection and climate change, support to non-state organizations involved in human development, food security and migration issues, (EC) No1905 [1]. It may come to aid to local population in health sectors, education, housing and so forth as it is currently the case of European Union to the people of Burundi. They support civil society organizations to promote the atmosphere of good governance and protection of human rights, protection of natural resources, state building in post-conflict cases; it is also given to support national budget. It can include humanitarian aid meant to offer quick relief intervention to alleviate suffering infringed by man-made disasters and conflicts.

\section{Evolution and views on foreign aid}

Historically, foreign aid has received bitter criticisms in the developing countries most especially in Africa. From the 1970's, the dependency theorists viewed aid as a form of exploitation and selfenrichment: Only the elites become beneficiaries of nationally designed projected. On the site of the donors, neoliberals saw in Aid an extortion of resources, a long earned asset being dashed to impoverished nations incapable of making a best use of it to effectively come out of poverty. In the 80 's, conditions upon receiving aid were introduced, which in most cases were related to institutional reforms, good economic policies. The Washington consensus introduced the Structural Adjustment Programs (SAP) loans to deal with inefficiency of the state. This Conditionality was later viewed as rather hampering with sovereignty and dignity of countries because of their coercive nature. Jane and Toye [2] saw foreign aid as not only inefficiency to reduce poverty, but as means to foster dependency. In the 90's the wind of neo-liberalism of economy postulated that the world should go Democracy and any state ought to embark on political reforms making institutions as democratic as possible where good governance, respect of human rights and alike were favorable conditions that could make development and reliability possible. The political orientation of the country could determine how much aid it could receive. Aid could therefore be given to countries going aboard the way of electoral reforms, multiparty system and any other political act advocating democratic atmosphere. These aids were also given to nations coming out of long times of conflicts to strengthen peace building in the country, supporting electoral processes or to empower new political formation and civil society organizations. Other factors that could attract aid were prevailing security threats, not only because they destabilize the nation's ongoing development projects, they also derail donors' interest in developing countries. Countries can be easily supported to deal with criminal activities such as human trafficking, cross boarder organized crimes, environmental threats, mainstreaming of gender which are normally connected to poverty [3].

\section{Foreign aid and agencies}

After the Marshal Plan which was meant to support European countries after the World War II, on $13^{\text {th }}$ January 1960 was born the Development Assistance Committee (DAC) grouping donor countries to offer consultancy platform in regards to Aid. It merged later with other development agencies to form the Organization for Economic Cooperation and Development (OECD). The 2000
United Nations general assembly came to realize that some parts of the world were still in abject poverty and the assembly adopted the Millennium Development Goals (MDGs) that could be summed up in 8 specific objectives: The focus on primary universal basic education, eradication of poverty and hunger, reduction of children mortality and maternal health, combating communicative diseases (HIV-AIDS, Malaria) ensuring environmental sustainability and strengthening of partnership among nations. These goals were to be endorsed and adopted by all nations and approved by the donor community. In 1969 the DAC later adopted the Official Development Assistance (ODA) to standardize the measurement of the source flowing from the DAC governments donors to developing targeted countries. Besides these well-structured donor agencies, we have private contributors giving loans in forms of bilateral cooperation. The selection of recipients are mostly based on set indicators, poverty status, political situation, level of respect of human right [4].

\section{Failure of foreign aid in alleviating poverty in developing countries}

In most cases, the aid in forms of economic bail out has been seen as a form of economic exploitation and defective as it tends to rather deteriorate existing economy as in the IMF-related fiscal target always compel the recipient to adopt measures with harmful effects at a long run. In the course of the loans processing, conditionality such as government's withdrawal in social services delivery, hinders government services' expansion and so therefore productivity. Workers are only contracted on part-time basis without being on payroll. As the aid does not come all at once, there is always lacuna in its efficacy. Delays in implementation of projects are due to aid's volatility and unpredictability. It fails have a positive impact as can't be used for a long term investment. Carlos and Nicholas, assert that as it pass through a lengthy bureaucratic process where corruption, mismanagement and misuses make the given aid quite useless. The IMF-based aid retrenches the operation of the public sector by freezing public sector hiring, the retreat ratio increases and social services are NGOized while basic social services delivery are put in hands of private business entities and by so doing, do increase poverty and suffering of the poor who can't afford social services any more. This raises the antistate sentiment when new political formations are dictated by a new economic order.

\section{Foreign aid seen as exploitation}

Abundant theories and literature list numerous sources of failure of Foreign Aid but most of them converge on the fact that, Foreign Aid are short term interventions lacking lasting sustainable impact. Some of these blame the world economic structure where LDC are put in perpetual dependency. A mixture of internal and external factors makes aid not be geared towards people's welfare but a long term gain for donors. African political economy is a product of western imposed models and ideologies. My candid view remains, African nations' development may still depend of the willingness of the world powers to give space to nascent economies on their own, or simply depend on the willingness of development nations to set priorities and agenda aimed at standing on their own to design their own fate.

Foreign Aid has always been the last resort of most African nations as its acquisition has not demonstrated much laudable and commendable outcome and here goes the saying that, between two evils, the lesser is preferred. As Morrison [5] noticed, Foreign Aid can only be beneficial if it can positively affect the investment, makes it possible for countries to import capital goods or technology and 
does not directly affect the savings rate. Many scholars converged on some factors making Foreign Aid not to work in developing nations especially in Africa: McGillivrray et al. [6] state that it decreases returns as it is mostly heavily influenced by external conditions and also, its relevance in the overall economic growth depends upon the nature and performance of political institutions in place. Foreign Aid is normally contracted for specific reasons: promoting long term economic growth and poverty reduction, to promote the short-term political interests...for Ali A.A.G [7] Foreign Aid remains unfavorable and ineffective as it remains volatile: The mode of disbursement is too lengthy and cumbersome and hence, the country fails to meet the time constraints projects have to take before completion. [8] affirms that the unpredictability of aid flows does not bolster good governance in no way; it hinders coherent government expenditure, or the development of sound institutions' accountability in recipient countries. In Ghana as in many African countries, the history of Foreign Aid showed a relative fiscal stability at the expense of employment at the era of Structural Adjustment Programs. [9] showed how, despite the long relationship with the IMF, the country remained solely dependent on cocoa and gold export. Its recourse to IMF loans where mostly in times of fiscal deficit, high exchange rate and inflation, increased debt and borrowing making the government unable to stabilize the economy.

Elsewhere, though Foreign Aid could increase the access to social amenities and services, such as a relative rise in school enrollment for the basic education and health, this could not follow the increase of facilities and quality of services in those facilities. In some studies made, [10] saw that it can only stabilize deteriorating poverty but not improve the situation, simply because it can take a longer time before the impact can be felt. Experiences however differ in many nations as Aid is meant to solve diverse problems but in most cases, its volatility and unpredictability makes it difficult for countries to factor it into long term spending plans and include it in budgets and therefore, its efficiency is questionable. In their study, Pycroft and Marthis [11] showed how donors may prefer to release their funds to solve problems other than the sectoral priorities set by the governments where these funds are highly managed by their own experts and or by independent NGO's which are merely implementers of already designed projects. Funds meant to help governments achieve its mandate to combat poverty and alike may be directed by foreign policies of hidden economic or political agenda whereas, they must be subjected to adhere to conditions hard to meet, meant to enable its best utilization. Good signals of good governance, liberty and freedom of the citizens, security and human rights, constitutionally laid down governing system allowing participation and democratic institutions to operate; are those dependant variables if trespassed can result into freezing, withholding or withdrawal of aid. One may now ask if we still need foreign aid and in case we don't, what can be the alternative of our so dependant economies suffocated by both endogenous and exogenous factors.

\section{Conditionality and its real impact on aid}

Along history, Foreign Aid has been viewed in different angles by both recipients and donors: In 70s it was criticized to be a form of domination and exploitation as it always fall in the hands of unprepared grounds, in the hands of leaders with no real vision, weak institutions and corrupt officials. In 80's, with the rise of neo-liberalism, Foreign Aid was seen as harmful to local economies and the Washington Consensus came with unbearable conditionality hard to be met. In 90's, these Conditionality whose greater part was to obstruct any socialist policy formation in the countries under development, they imposed a democratic regime with a full capitalist economy. This also led to the formation of political parties and allowed competition on the political scenes to gain power [12]. This was meant to deny over tenure on power and a possible dictatorship which could hinder development and do away with western interest. It was toward the end of this period that we had nascent issues of security, like terrorism that drew attention of donors on matters concerning migration, etc. After this era, the world economic crises made poorest countries to be highly indebted and the London Club had to persuade creditors to be conscious on aid and impose Conditionality to countries receiving Foreign Aid so that they may put in place measures that could make it possible for them to pay back [13]. This Conditionality was seen as substitute of collateral assets as donors ensure that there is a clear and sound economic policy which will enable aid yield fruits. Other analysts saw them as safeguard to moral hazards. This could be more frustrating when donor countries send their own experts to monitor the usage and usefulness of the aid to persuade and encourage the implementers to adhere to pre-established agreement. Though this can be a way of ensuring being paid back, it has been also a way of imposing economic policy to countries as many name it imperialist way of keeping a hand on the management of affairs of other nations for their own gain [14]. Despite this bitter criticism, Foreign Aid, if well utilized, Rodrik [15] saw that it can improve domestic economic policies by inducing consistent flow of income over time. Here is the justification.

\section{Justification for conditionality}

Aid is always given under Conditionality whose acclaimed aim is to ensure effectiveness in resolving problems for which they were to resolve. This aid can be withheld, removed or cancelled in times of trespasses or failure to adhere to Conditionality which are seen as sine qua none factors making aid yield results. Among many of these, good governance and the rule of law have been identified as fertile grounds where aid could produce good fruits. Simply because the conducive political environment can foster accountability, formulate good policies which enable transparency and practice of human rights, respect of legal foundation of the state, constitutions and other political governing precepts. It is a view that such an institution can offer a good environment for business and facilitates investment and protects interest of the people and their properties. In 1990's France warned its partners to forcibly democratize institutions as they sought to enhance institutional strengthening more especially in electoral processes and other institutional arrangements capable of making reforms possible.

\section{Failure of Foreign Aid's conditionality to reduce poverty}

Again, imposed conditionality has demonstrated a very minimal impact on policies. The Foreign Aid which is a disputed form of domination by some people was seen as ineffective when, it falls into wrong and poor programs and policies, where there is poor or lack of monitoring mechanisms from donors to avoid principal agent dilemma. The other non-negligible factor is the ownership of policies. If suggested policies are from political leaders who are the same implementers, there is likelihood that the aid yield fruits. But, if the policies are a form of imposed programs, it may not match with the realities and the needs on the ground, which will eventually result into failure of aid. To be successful, there should be coherence between the donors' plans of actions and what the country aspires to achieve as objectives because the two may be conditioned by different drivers. This often happens in rural development projects where programs are drafted in high offices with less or no real a priori research to determine what is really needed by beneficiaries as they are not involved in policy elaboration. Other factors may come from global current economic and political situations where new measures (health, security and 
environment) may need to be imposed to nations for the general good. One of the other factors occasioning failure of the aid is that they resolve existing problems and fail to dig deep and tackle the grassroots issues. On one hand, conditionalities' positive impact can be good only where aid is meant to tackle a real problem the society is facing. On the other hand, the non-adherence to conditionality may hinder the performance of aid especially when it is aimed at reducing poverty. The question here is easy to answer. If Foreign Aid is something that has been in operation since 70's what accounts for the current state of poverty of nations that have been receiving aid over several decades now? Part of the answer is, the aid always falls into unprepared grounds, and donors do not care about pre-donation situation but care much about post-donation periods. Burnside and Dollar [16] assert that it can only spur growth if it is channeled through well-established economic systems allowing its best use. They add that aid can only have positive impact on growth in developing countries which have adopted good fiscal, monetary, and trade policies, otherwise, the acquisition of aid will compel those systems to install first sanity in fiscal and monetary policy. In the presence of poor policies, aid has no positive effect on growth whatsoever. As any other pro neoliberal theorists, the government whose concern remains on social welfare provision (Education, health, housing...) may not meet the target as these services remain unproductive, but mere government expenditures.

Most scholars do not commend Foreign Aid as they qualify it as impediment and intrusive in as much as their positive impacts remain unmeasured. For them, unless it is contracted to accomplish already started projects, it rather weakens feeble state's ability to deliver unless it supports ongoing state-owned, negotiated and implemented ones with no conditionalities.

\section{How foreign aid can be beneficial}

In relation to growth, aid is not always to be seen as useless though we still need to investigate where it has ever shown good outcome. Lipton, Toye and Cassen [17] made it clear that, though it may not bring about growth, it may help in poverty reduction. It may also increase the cash flow without benefiting directly the needy ones. Where Foreign Aid seemed to create much impact was where it was linked to projects aiming at attaining the Millennium Development Goals or supporting national budgets or used for public investment.

Hassan [18] argued that, foreign aid is not evil in itself to our African economies. It must only support existing started projects, increase import, technology transfer and strengthens national currency, lower inflation and minimize devaluation of the economy. Rather than cutting down the expansion of provision of social welfare services, it has rather the obligation to make its provision more inclusive and extensive as many rural African zones still needs government's intervention to raise the leaving standards up. Unlike other scholars, he thinks these aids should rather be meant to improve social services as an investment in people will be more beneficial to our nations rather than investment in areas where benefits are shared among a few elite. The aid that is not meant to improve infrastructural constraints, to improve the leaving standards of the poor rural zones still living on rudimental agriculture of substance, the foreign aid which is not addressing the issues agriculture today, aid which is not meant to reduce poverty by implementing people-centered projects, empowering the lives of the marginalized citizens, aid which will not lead to macroeconomic development...would eventually lead to a failure because the cause of our lagging behind would not have been touched.

Conclusively, Foreign Aid can only yield results when it is consecrated to improve lives of the poor ones through variety of empowerment programs (both for woman, unemployable youth and vulnerable). It should help the government generate employment which will increase their living standards and the level of consumption. It can have positive impact when it facilitates technology transfer, invest in research and high education, build strong competitive market and freedom of all sorts to create enabling environment for investors. Where things have been better, loans and grants were able to facilitate the expansion of small scale businesses, credit unions, microfinance, savings and loans institutions, agricultural cooperatives in rural areas and many more services empowering the most impoverished, but also supporting nascent development third sectors' development projects. To some extent, the foreign aid should not attract any conditionality that will make the poor poorer and rich, richer. It should be given and foremost, be contracted when it is most needed and not be taxable and impose external conditions which are likely to make it fruitless.

\section{Other Alternatives for Poverty Alleviation in Africa}

\section{IMF loans and bail out: Overview}

IMF loans are financial assistance contracted by a country experiencing economic hardship beyond its ability to manage. They come in forms of short-term loans aimed at doing away with financial deficits. The contracting parties agree on some conditionality upon reception of the funds, whose main purpose is the guarantee its usefulness and the ability of the contracting country to pay back. They are measures imposed to the countries laying down economic policies meant to readdress the situation that led to the need of borrowing. Fiscal policies are imposed compelling the government to reduce public spending and borrowing: It is in most cases cutting down number of subsidies, privatizing the social services delivering institutions, etc. African governments have been contracting these loans seen as harmful to the overall economy by most researched made, though it has been the necessary evil in some cases.

Let's remind that the IMF and the World Bank, in their early conception, worked on the quota contributions from member countries. Each country had to pay to the fund according to a quota. This fund constitutes the basic source for loans to country members in order to correct balance of payment issues. Different types of loans from the IMF are linked to the size of national quota measured on the basis of a formula which includes the country's national income, foreign exchange reserves, size and fluctuation of its foreign trade, export dependence and many more factors [19]. The sum the country can take away from the fund is determined by its quota. The first $25 \%$ is not subjected to any conditionality but the remaining three must be taken after a standby agreement has been signed and this agreement consists of the Fund's directives to put in place and implement stabilization program called conditionality at times going along with authority measures to foster fiscal discipline. The Fund later established the Extended Credit or Fund facility (ECF/EFF) allowing countries to draw beyond its quota up to 3 years if it is able to implement an economic stabilization program agreed by the Fund and adhered to performance criteria.

The IMF loans are seen as funding programs that comes in times of serious imbalance in the economy, when there is a huge account deficit, high inflation caused by malfunction of the economic system or when experiencing deficit in the domestic budget. The IMF loans are contracted to correct these imbalances and three types of policies are imposed to come out successful: Policies restraining demand (restricting government's expenditures, limiting credit creation, 
increasing taxation methods and revenue collection, restricting net hiring etc), policies meant to redirect the resources towards tradable (work on the exchange rate devaluation, price reform) and policies meant to readjust the economic performance (financial reform, import liberalization. The historical accounts of the IMF loans traced back to 1980's showed that the implementation of these three type of policy has rather hinged on the overall well being of the people as the rise of unemployment in the priority sectors (health and education) have led to deterioration of living standards of already poor citizens. The outcome could be gravely be felt by all sectors of the economy and could worsen cases because conditionality imposed could not work well in all cases. It was shown that, where the little success could be marked was where funds were injected in long term investment projects that strengthened job creation and employment in the informal sectors.

The WB bail out have been characterized by constraining fiscal and monitoring policies namely: a residual government's intervention in social services delivery, the privatizations of key social services provisioning institutions and state owned enterprises, import-export liberalization, higher interest rates, freezing of net hiring in non priority sectors . In their quest to arrive to sustainable economic growth, they tend to engage the government to implement measure that can lower the inflation, rebuilding the foreign exchange reserves.

\section{IMF loans/bail out effect on the economy}

The case of Ghana: We have earlier noted that the government calls upon the WB bail out for multiple and varied reasons: policy support, partnership in projects' execution, technical support or funding ongoing programs. Ghana had had lasting relationship with the IMF since Kwame Nkrumah's government. The recent recourse to IMF was dictated by unfavorable economic conditions that the country faced. In 2014 and some few years earlier agreements were signed between IMF and the government once again or a three year Extended Credit facility which was a programmed stabilization program after the country had continuously experienced significant domestic and external vulnerability on the back of a large fiscal deficit slowing down the economy by raising the inflation. Sydney and Godfred [20] showed how all these were caused by weak revenue performance, large wage bill, rising cost of debt service, decline of import due to the depreciation of the cedi, the economy incapable of providing import substitute due to weakened manufacturing industries as the energy crisis strongly hit the sector. The lack of government's expenditure restraint and the continuous central government's borrowing because if its inability to go by strict monitory policy framework which rather accumulated public debt over time. The country had no other alternatives than to appeal for IMF's intervention.

The IMF's intervention in Ghana's case was not to allow a smooth cash flow but fiscal discipline. It came to install sanity in the financial management where expenditure were to be monitored, wastage cut down, corruption minimized and mismanagement checked. It was in a form of austerity measures whose emphasis was to restrict mass employment, job cuts, freezing on public sector recruitment etc. Together with some homegrown strategies, (tax administration review, slowing down the government's expenditures (declared in the Wenchi Consensus), these measures were to be implemented upon reception of the help.

Besides other conditionalities, the so called benchmarks were attached to the loan: freezing net hiring in key sectors, measures were to be implemented to control the inflation, monitory tightening and revenue collection especially on the utility services providers.
Readjustment of petroleum tariffs was an order of the day, tax policy and administration was to be checked while public sector management consisted of cleaning up the payroll. Revising most revenue collections methods and all these measures were to be implemented in 5 different areas according to IMF [21]. First, the macroeconomic framework where adjusting and restoring the debt sustainability, elimination of fiscal dominance of monitory policy and working on fiscal consolidation policies by for instance making sure that the energy crisis was minimized. The second area was the fiscal policy that embraced a whole range of activities. The third area was the structural reforms to strengthen public finances and fiscal discipline. This included minimizing the public sector spending, budget transparency, payroll clean up, wage bill control, restructuring of the statutory funds, improve revenue collection, natural resource management etc. the fourth area was the monitory policy and the management of the exchange rate regime which was to deal with inflation reduction, central bank financing central government and state owned enterprises to be eliminated. The Fifth area was the economic growth and social protection agenda. This was to adopt new targeting methods in programs dealing with social protection and safety net services. The national household registry could improve funds management. Buxton and Ampah [22] added that a gradual shift of public expenditure from current to capital spending supported by the channeling the new oil and gas revenue into productive projects such as infrastructure and reliable power generation.

In the course of the IMF's program, the Government of Ghana was asked to defer the payment of GHC855 million to Ghana Education Trust Fund (GETFUND), the NHIS Fund and the District Assembly Common Fund (DACF). These measures fatally handicapped the ongoing projects in the districts levels. The net hiring freeze in non priority sectors will interfere with health and education as masses of trained nurses and teachers were not being posted. The deferred statutory payment to the National Health Insurance Fund will have a negative impact on health care on the deprived and vulnerable. The delay of DACF release will restrict rural districts to embark on local level infrastructural projects. In the study made by Bawumia [23], The District Assembly Common Fund (DACF), the Ghana Education Trust Fund, National Health Insurance Scheme, School Feeding program, Payments to government contractors were all in arrears on time of IMF loan cycling. The removal of subsidies on number of items saw fuel prices and utility tariffs galloping, what worsened the living standards of poor people. For him, for the IMF bail out to work meant the Labor Union association should not demand better wage increase as the government would be compelled to increase salaries, what will be a trespass to the conditionality of the loan. Industries will be laying off workers as the power crisis persists... The Ghana Statistical Service showed how prices of commodities have highly increased; inflation was not being stabilized. On the economy, a consistent decline of public investment has further hindered economic growth. In the study made by Benjamin et al. [9], going by IMF dictates of deferring domestic payments to local suppliers, the government of Ghana in 2009 accumulated new domestic payments arrears to suppliers of goods and services to the tune of $\mathrm{GH} \$ 855$ million against a 2008 figure of GH\$830 million. The study showed that these arrears greatly affected payments in the energy, roads and other Ministries, Department and Agencies (MDAs) projects. Also, the accumulation of payment arrears constitutes proxy borrowing by Government which locks up working capital of suppliers of goods and services to Ministries, Departments and Agencies (MDAs) of government.

This is just a smaller view of the impact of the IMF loans on the 
life of the economy, especially the social sectors. No tangible proof has indicated that with IMF loans things could get better during and after its implementation.

\section{Non-government organizations in developing countries}

If the Foreign Aid has been seen ineffective to reduce poverty in poor countries, there should be other alternatives. In many African countries, there are influx of non-state controlled development entities and agencies which complement the efforts of the government to supply goods and services to the people. Most of these are non-profit making organizations operating as independent bodies involved in social services delivery. Some are local while others are foreign initiatives, institutionalized and well organized bodies staffed with professional administrative personnel working across nations. Reaching out the people far better than the government, these nongovernment organizations (NGOs) may work with local organizations for capacity building, social services delivery, poverty alleviation programs such as relief services, improvement of health or involved into education sector as supporters and partners of the local education system. Some of these organizations work hand in hand with local organizations to advocate for human rights or. Some are faith-based institutions promoting welfare of their members through a variety of schemes. The larger organizations have wider scope and can support grassroots organizations which in most cases are faith-based bodies known as grassroots organizations (GROs) working as mere issuebased ephemeral which cease to operate when the problems they intended to solve end.

In early 70's NGOs were not known yet in the sphere of projects' development. They were perceived as short-term relief services providers, whose real impact could be seen in emergency response and their visibility came to bear in late 70's with adoption and implementation of structural adjustment programs where the state relinquished and withdrew its direct intervention in basic service delivery, what increased vulnerability and poverty especially in developing nations. The state was found incapable of assisting its people and donors preferred channeling their aid into the hands of these NGO's Lewis [24].

Since 1980's NGOs were seen as the last resort in development and were bridging the gap widened by the state's inability to reach out the needy citizens. Operating as non-state entities, these humanitarian organizations were founded on philanthropic basis to assist the state meet its obligation to the people. They are known for their usage of innovative and experimental approaches centered on community participation Bebbington et al. [25].

As studied earlier before, NGO's roles were more seen in the areas of advocacy, human rights advocacy, and empowerment and as capacity builders by providing what the state was not able to offer. They had to fill the gap created by the market where they serve as evaluators, auditors and were self-designed to solve matters of public interests. Operating in most rural zones, they locate their services where they are most needed. They have been playing tremendous role in institutions' accountability. Nair [26] studied that in Pakistan, Bangladesh and India, the political situation of the country is determined by the level of NGOs; which fostered and called for equal representation in governance. However, Clark [27] discovered that NGOs emerged in Indonesia and Vietnam as the state's hegemony to expand the limited political space available to civil society. In other parts of the world, [28] saw that in Uganda, they were used as giving patronage networks of political leaders unlike in Latin America where according to Drabek
[29], they have rallied with opposition to strengthen the role of the civil society where they can be used to mobilize and sensitize the poor of their conditions, appealing on behalf of the marginalized for a possible change. Again, in most Latin America, they were seen as democratizers and social change triggers and played a major role in political reforms and remained active in state-societal relationship.

The roles of NGOS: Instead of relying on loans of IMF and other international institutions that impose conditions and remittances beyond the nation's ability to bear, some countries allow these NGOs partake into the formulation, design and implementation of development projects as they don't require any sine qua none conditions and they become part of the vectors of development in the country. What makes them more effective and better than the foreign aids is that, they don't only offer their financial assistance, they also empower the less advantaged portion of the population by promoting good governance when they advocate for human rights, environmental protection and sustainability, fight against abuses to vulnerable people (children and women) and encourage participation of the population into the development processes of nations [30]. Unlike bilateral donors injecting funds into corrupts governments, NGOs have research department and policy units and they respond to known problems and they resolve concrete problems with or without government's intervention. But, at times, they do involve local governance for transparency sake and mutual accountability and risk sharing. In the south, NGOs can be a source of change as they play advocacy role and act at times as part of the civil society to exercise external pressure to governments and foreign donors to commit themselves on vital issues. They can also compel donors to honor their promises or be the carrier and bridge between the government and their donors because, foreign aiders may relinquish releasing funds through governmental institutions with low credibility by lack of confidence, but prefer supporting NGOs initiatives. Besides, faith-based NGOs such as Christian Relief Services and some Muslims' organizations, ally with these NGO's to champion causes of the poor majority of the people. This may be through sensitization and mass education for instance prevention, control and management of communicative diseases, environmental protection etc.

Efficiency of the NGOS: First, NGOs are flexible, well equipped, funded and staffed. They are well informed on the needs on the grounds and reach out remote places and penetrate rural zones hardly visited by government officials. Their major roles here are a twofold mission: Services delivery and policy advocacy. In the social delivery, they are into a whole range of social welfare provision. This may include community development programs where health services, education, sanitation and housing are improved. Their role is mostly felt any time the government adheres to austerity measures and withdraws from social welfare provision when most concerned institutions go private. They are there to fill the gap left by residual government's intervention. In this era of neo-liberal economy, the government's prime interest is in profit maximization, competition with global economies and any time they contract foreign aid, they are remanded to adhere to the idea of cutting down government's expenditure.

Secondly, the NGO's are into advocacy where independent researched works are used to request for assistance and aid. They constitute the bridge between donors and poor countries as they have a wider international coverage and their publications serve as testimonies which at times are been based on to intervene and help. On local level, they enforce, influence public policy as they campaign for people's rights by protesting against violation of human rights by both citizens 
and governments elites. Fisher [31] noted their role in environmental protection. In southern America and Eastern Asia, he showed how they have contributed to the acceleration of democratization of institutions and in enforcing the rule of law. They have been supporting coalition movements and compelled governments to opt for sound policies. In most cases, NGOs are labeled as other forms of western domination and they rather prefer to empower the local organizations to remain neutral as most projects are executed for some political ends.

Third, more than governments, NGOs are innovative, adaptable and flexible. They are better informed and most of their activities are cost effectives as they hire interns and volunteers who don't require many payments. They fill the gap left by the government and may participate in job creation more especially in rural communities.

NGO's shortfalls in poverty eradication: In this study, if these organizations have laudable projects of such magnitude, why do we still experience poverty at a high level where their presence is so condense? The relationship between the state and the NGOs in services delivery is most times marked by conflict of interest, duplication of policies: rendering the same services to the same beneficiaries. NGOs fail to eradicate poverty for the following reasons: Their choice of location plans of activities, duration and scope of operation depends on donors' geopolitical priorities. Their intervention tends to align with political, economic and social agenda of the donors. These donors implement short-term projects and fail to tackle real root causes of problems and this make NGOs incapable of creating significant impact. Their intervention is to resolve an existing problem and not proactively fight the causes of issues. They are so much concerned in professionalizing their services to meet the donors and beneficiaries positive appraisal and requirement for their own survival. Their life span depends upon the donors' ability to supply funds as most of them are non-profit making entities and, the prevalence of the conditions leading to their presence in the area. For them, we can sarcastically join Hudock [32] who states that, 'poverty must remain for them to survive'. Others identify lacuna in the field of NGO's operations especially local organizations where, there is a lack of synchronization of services as some tend to offer the same services to the same beneficiaries. Elsewhere, poor monitoring and lack supervision make their activities' visibility inaccessible as they have their own internal evaluation modules. This is when their activities are short-lived with immeasurable impact as the same issues occur later after they have left because they are interested in tackling emerged problems not their causes. Relief services are not adequate for poverty reduction and what is needed is a proactive approach seen as preventive. In some cases, they work within political boundaries where they have limited access to some key areas. Their activities are spontaneous and act when funds are available; hence they lack strategic planning as donors' funding remains unpredictable.

\section{The African home-grown initiatives: Nepad's case}

In response to the failures of the Structural Adjustment Programs' ability to redress African economies, what could our continent take as alternatives and what have been the results of those home grown initiatives? In its own discourse to deal with its own development predicaments, several local or foreign interventions have been in operations seeking to find ways the continent's lagging behind could be mitigated. The Lagos Plan of Action of early 1980s and subsequent continental joint efforts ignited series of actions in the realm of economic cooperation and political integration. The African Priority Program for Economic Recovery of 1985, the Cairo Agenda for Action of 1995, the UN program for Accelerated African Recovery and Development (UNPAARD) of 1986, The UN Economic Commission for Africa (UN ECA) of 1989, the OAU's Charter for Popular Participation in Development in Arusha in 1990, the UN New Agenda development in Africa of 1991, the AOU's Abuja Treaty for African Integration and Development of 1991 where the African Economic Community (AEC) was launched in the same year; here came the African Common Market Agreement and eventually the creation of the African Union and many more commissions of cardinal importance. They laid foundations which were initial attempts to rethink ways which could render African economies more vibrant, independent and prosperous. None of these created a real difference and poverty remained rampant and fast growing though there has been relative positive change in some nations. The New Partnership for African Development (NEPAD) came as a well thought and designed new re-engagement to lay solid foundation for the renewal of African condition whose projects were being supported by governmental efforts, Regional Economic Committees (RECs), multilateral development institutions, United Nations' key departments and many development agencies. Inspired by African conditions, it was prepared, owned, designed, developed, adopted and implemented by African leaders and the role of the international community was solely in the realm of support and funds activities [33]. NEPAP and its main component African Peer Review Mechanism (APRM) was to compliment earlier established African initiatives by recognizing where help was needed most and by redefining what seemed a priority to most countries: Sectoral priorities were to bridge African infrastructural gap by closing the divide in the sector of energy, transportation, watersanitation, adoption of human resource development initiatives. But also, to enforce the pledge of national leaders to advance democracy, promote sound economic management, peace and security and people centered development projects by help of its African Peer Review Mechanism (APRM). The pillars of the NEPAD were to eradicate poverty, to put African countries on the path of sustainable growth, to halt the marginalization of the African continent in the globalization process, to integrate the continent in the global economy and accelerate the women's role in development. In all these, it anticipated the help of national governments to achieve the Millennium Development Goals in most African countries, which was hailed by the G8, supported by the AU and its stakeholders in development [34].The APRM was its well thought means and tools to foster good governance and all that could create conducive environment for NEPAD's projects' successful implantation. This was done in forms of questionnaires distributed to national governments as a self assessment means to inform on the state of economic program on courses and measures being implemented to advance the course of the program. The set up team was to review the forms and formulate action plans to the country support mission and so far, Rwanda, Ghana, Mauritius and Kenya were able to be assessed for this end. The APRM's failure meant the failure of NEPAD as it was its right arm. Part of its failure could be accounted to the fact that it was a voluntary initiative that had no formulated sanctions and punitive measures to enforce compliance to adhere to set norms, which according to donors made it look like a toothless tiger. Its missions couldn't work in countries where no conducive political and economic environment was possible and national leaders understood differently its functions.

NEPAD's Incapacity to achieve its goals: Despite its warm welcome in many nations and massive external support, NEPAD like any other program earlier designed for Africa, had its own potentials to break this vicious cycle of increasing poverty, underdevelopment and it was the long awaited program that could counter global powers and clean up messes left by the SAP's implementation. It was to be the remedy of African ills out of western direct powers... NEPAD 
and other earlier mentioned initiates, such as the Alternative African Framework to Structural Adjustment Programs for Socio Economic Recovery and Transformation (AAF-SAP-SERT), later called AAFSAP, they were to be the successful economic and social self-sustaining forms of indigenization of development process by implementing self-reliance projects (in trade) and in regional cooperation. Their real impact remained impalpable and reliable enough to ascertain comparative change for these simple facts: Policies were of a top-down approach of course of action that had not involved the key social policy implementers and designers which are essential in development: The NGOs and the CSOs which have their unique ways of raising awareness of priority issues and being more informed on the grassroots level are not being consulted in policy formation but are invited to help in implementation [35-40]. The other imminent possible causes of failure was the conflict of interests among top overseers where ownership of NEPAD's policies seemed South African under Tabo Mbeki's leadership from its incisions to its implementation while top leaders and promoters where Nigerian president (O. Obasanjo) Algerian president A. Bouteflika and A. Wade the Senegalese leader. In NEPAD, though a lot has been done, the lacuna remained looking at the magnitude of issues to tackle. Countries have different urging economic needs and as there has not been a common denominator the African Peer Review Mechanism (APRM) could not have easy access to countries' statistical data base, it remained ineffective and as it stands today, in some countries like Ghana, South Africa, Senegal, Rwanda, Algeria and many more, it's obvious it had done some laudable projects but Africa is not just that. If Africans can now proudly stand out and proclaim aloud the economic liberation and whatever goes along with it due to NEPAD's projects, I will be so much surprised. Meaning, NEPAD is likely to die off without realizing its mission [41].

\section{Conclusion and Recommendation}

A paradigm shift needs to be drawn for the scope of foreign aid in developing countries to yield fruitful results. Putting recipients in perpetual state of dependency, foreign aid has not proved any basis to be relied on as conditionality attached to aid makes it inefficient to eradicate poverty: stabilizing the deteriorating economy, the yardstick of take off can't be accounted on aid as long as vulnerable category of the poor experience harsher conditions when some social services are withdrawn or put in the hands of profit making bodies, when key social welfare providing institutions are privatized. In this study, it was shown that no matter the form of foreign aid, its relevance in the poverty reduction remains questionable: Being short-term programs addressing already identified superficial issues, they fail to offer a more lasting solution to vital societal economic dilemma. In most cases, the hard to meet conditionality such as the ban on employment worsen the situation, the living standard of the poor citizens ....especially when utility bills go up, when tax increases and the local currency depreciate causing inflation to discourage the lower income families. The question was what could be the alternative for countries to do without foreign aid. The non-government organizations, civil society, which were seen to play a vital role in the development of a country, face their own internal and external predicaments rending their services dependable, conditional and fail to make difference at a higher scale. Working individually under different politically and economically oriented donors, their work could be meaningfully assist government's mission by synchronizing their services and collaborate with the stakeholders (the state and donors) both in policy formulation and implementation. The homegrown initiatives started by African leaders have not yielded any reliable results to be based on to imagine a brighter future. The papers however identified ways to go by so as to avoid IMF bailout caused by excessive payment imbalance due to many factors: In most cases, revenue hemorrhage caused by improper tax administration, government's over spending and borrowing... This could significantly be reduced when rigorous domestic revenue collection strategies, tax reforms, laying down stronger institutional reforms, fighting corruption and all conditions leading to revenue and public funds evasion. Not refute foreign aid as such, its usefulness will occur when contracted to be used in the government's short and long term public investment (infrastructure) and human capital (health and education) which is likely to create enabling environment for industries, foreign investors. To yield results the foreign, once directly injected in the productive investment projects, making it possible for the gain of the weight of local currency... Conditionality attached to it should be waved so as to maximize its usefulness. It can also be used in institutional consolidation and building to create fertile grounds enabling transparency and confidence from donor community.

\section{References}

1. Ali AAG, Mwalwanda C, Suliman Y (1999) Official Development Assistance to Africa: an Overview. Journal of African Economies 8: 504-527.

2. Asante SKB (2006) Implementing the New Partnership for Africa (NEPAD) Challenges and the Path to Progress. Ghana Academy of Arts and Sciences, Accra.

3. Bawumia B (2015) The IMF Bailout: Will the Anchor Hold. Central University College, Accra.

4. Bebbington A, Hickey S, Mitlin D (2008) Introduction: Can NGOs make a difference? The challenges of Development alternatives. pp: 3-37

5. Benjamin A, David K, Jody W, Mensah O (2010) Implications on IMF Loans and Conditionalityon the Poor and Vulnerable in Ghana. ActionAid Ghana, Accra.

6. Brass JN (2012) Why do NGOs go where they go? Evidence from Kenya World Development 40: 387-401.

7. Burnell $P$ (1999) Britain's new government, new White Paper, new aid? Eliminating world poverty: a challenge for the 21 st century. Third world quarterly 19: 787-802.

8. Burnsid AC, Dollar D (1997) Aid, Policies and Growth. World Bank Policy Research Working Paper No. 569252

9. Buxton JK, Ampah SK (2015) The IMF \& MCC requirements to Ghana: Economic Report. GN Research, Groupe Nduom, Accra.

10. Clarke G (1998) Non-Government Organizations (NGOs) and Politics in the developing World. Journal of Political studies XLVI: 36-52.

11. Drabeck AG (1987) Development Alternatives: The challenges for NGOs: World Development 15 ( Supplement) ix-xv.

12. Edwards M, Hulme D (1992) Making a Difference: NGOs and Development in a Changing World. Earthscan Publications: London.

13. Ebbington A (2005) Donor NGO relations and representations of Livelihood in non-governmental aid Chains. World Development 6: 937-50.

14. (EC) No1905 (2006)Supura note 26, art 20, Annex.

15. Fallon J, Sugden C, Pieper L (2003) The Contribution of Australien Aid to Papua New Guinea's Development 1975-2000. Evaluation and Review Series, No.34. AutralianAid: Canberra.

16. Francis S (1987) Should Conditionality Change? in Kjell, J-H. (1987) the IMF and the World Bank in Africa. Conditionality, impact and alternatives: Scandinavian Institute of African Studies: Uppsala.

17. Fisher J (1998) Nongovernment: The NGOs and the Political Development of the Third World, CT Kumarian: Hartford.

18. Ghana Statistical Service (2014) Ghana Livings Standards Survey Round 6 : Report,Accra: Ghana Statistical Service.

19. Gillary M, Hermes N, Lensink R (2006) Controversies Over The Foreign Aid It works, It doesn't, but that depends" Journal of International Development Vol 18. 
Citation: Niyonkuru F (2016) Failure of Foreign Aid in Developing Countries: A Quest for Alternatives. Bus Eco J 7: 231. doi:10.4172/21516219.1000231

Page 9 of 9

20. Hadjimichael M, Dhaneshwar G, Martin M, Roger N, Murat UE, et al. (1995) Sub-Sahara Africa: Growth, Savings and Investment,1983-93, Occasional Paper 118, IMF: Washington DC.

21. Hassan UM (2000) Role of Foreign Aid: A Critical Analysis. Tha Netional. Kardar, S. (1995) Political Economy of Pakistan. Ferozensons. Lahore.

22. Hopekins R, Powell A, Gilbert, CL (1997) 'The World Bank and Conditionality'. Journal of International Development 9(4).

23. Hudock A (1999) NGO and Civil Society: Democracy by Proxy? MA Blackwell Publishers Inc.: Malden.

24. IMF (2015) Request for a Three-year Arrangement Under the Extended Credit Facility. Staff report; press release; and statement by the executive director for Ghana. IMF Country Report No. 15/103. Washington, D.C.

25. Jane H, Toye J (1995) Aid and power: The world bank and policy-based lending. By Paul Mosley, Jane Harrigan and John Toye 1: 317.

26. Kjell JH (1987) The IMF and the World Bank in Africa. Conditionality, impact and alternatives: Scandinavian Institute of African Studies: Uppsala.

27. Lewis D, Kanji N (2005) Actors, Ideas and networks: Trajectories of NonGovermental in Development Studies. Zed Books: London.

28. Lipton M, Toye J, Cassen R (1986) In R. Cassen (ed.) Does Aid Work?, Oxford: Oxford University Press.

29. Marty L (2004) "Civil Groups want more seats at Policy table" Global information Network (27-10-2004) [database on-line]; available on ProQuest; accessed on 12-04-2016.

30. McGillivray M, Torresands K, Fieldings S (2001) "Does Aid Work For the Poor"
Economic Discussion Papers No.114. School of Business Studies. University of Otago Press: Dunedin.

31. Morrison O (2001) Does Aid Increase Growth? Progress in Development Studies 1: 37-40.

32. Mosley P, Harrigan J, Toye J (1995) Aid and Power: The world Bank and Policy based lending (10) (2ndedn) London: Rutledge.

33. Nair $P$ (2011) 'Evolution of the relationship between state and non-government organizations: a South Asian perspective', Public Administration and Development 31: 252-261

34. Oxford Analytica (2004) "Slow start for NEPAD Peer Review Process" (8 July 2004)

35. Pycroft J, Pedro M (2009) How Unpredictable Aid Influences Services Delivery: Literature and Data Review: Overseas Development Institute p33.

36. Riddel RC (2014) Does Foreign Aid really Work? Oxford University Press Oxford.

37. Rodrik D (1996) Understanding Policy Reform. Journal of Economic Literature 34: 9-41.

38. Sydney CH, Godfred AB (2014) IMF Program with Ghana: The Role of Civil Society Organizations. Center for Policy Education, IMANI report no 0231

39. Vanessa KS (2005) The New Partnership for Africa's Development (NEPAD will it succeed or fail? U.S. Army War College: Pennsylvania.

40. Vandana D, Robert BP (2002) The Companion to Development Studies: Oxford University Press Inc., N.Y.

41. Woods N (2005) "The Shifting Politics of Foreign Aid," International Affairs. 